\title{
Departments
}

\section{NEW AND FORTHCOMING AT REFERENCE}

\author{
Compiled by \\ Gladys I. Dratch and Doborah S. Garson
}

Benson, Allen C. and Linda M. Fodemski. Connecting Kids and the Internet: A Handbook for Librarians, Teachers, and Parents. New York: Neal Schuman Publishers, 1996. 382p. ISBN 1-55570-244-9. OCLC\#34951383. \$35.00.

Geared for teachers, librarians, and parents who want to introduce the Internet to young people. Provides an overview of the Internet, how to get connected, tools and resources, and communication via e-mail, mailing lists, and Usenet newsgroups. Chapters include "Rules, Security and Safety for Kids" and "Online Projects for Kids."

Camegie Task Force on Leaming in the Primary Grades. Years of Promise: A Comprehensive Learning Strategy for America's Children: The Report of the Carnegie Task Force on Learning in the Primary Grades. New York: Camegie Corporation of New York, 1996. 162p. OCLC\#35759792. \$10.00.

This third and final report of the Camegie Task Force, covering ages 3 to 10 , examines the major institutional influences on children: the family and community-based organizations, early care and education programs, elementary schools, and the media. The executive summary is available on the Internet by accessing either gopher. camegie.org or http://www.camegie.org. Prior Task force reports are: Starting Points: Meeting the Needs of Our Youngest Children (1994) and Great Transitions: Preparing Adults for a New Century (1995).

Chambers, Jay G. The Patterns of Teacher Compensation. Washington, DC: U.S. Dept. of Educational Research and Improvement, 1996. 65p. OCLC\#34510176. \$11.00.

Reports on the relationship between compensation and specific teacher and job characteristics: public and private school salary differences, teacher sex and racial-ethnic background, differences in school level and type, teacher qualifications and effort, and the impact of working conditions on salaries. Includes tables, references, and technical notes.
Council for Exceptional Children. What Every Special Educator Must Know: The International Standards for the Preparation and Certification of Special Education Teachers. 2nd ed. Reston, VA: Council for Exceptional Children, 1996. 145p. ISBN 0-865586-287-7. OCLC\#35016560. \$14.30.

A revised set of comprehensive standards and guidelines for the preparation and certification of special educators adopted by the Council for Exceptional Children in May 1996.

Divided into three sections: Part I provides general guidance for professional conduct, Part II presents the Council for Exceptional Children's International Standards for Entry into Professional Practice, and Part III is designed for use by special education professional preparation programs. Items in Parts II and III are coded by area, topic, and knowledge or skill.

Directory of College Cooperative Education Programs. Polly Hutcheson, ed. National Commission for Cooperative Education. Phoenix, Ariz: American Council on Education and Oryx Press, 1996. 219p. ISBN 0-87-774998-7. OCLC\#35096124. \$49.95.

Contains 460 institutions offering cooperative education employment to students. The data is based on a questionnaire pertaining to the 1994-1995 academic year. Arranged by state, each entry contains a general institution description, key contacts, co-op program description (including number of students placed in 1995), employers, and degree programs offering co-op. Index of institutions and list of programs and degrees index.

Directory of Curriculum Materials Centers. 4th ed. Beth G. Anderson, ed. Compiled by The Curriculum Materials Centers Directory Revision Ad Hoc Committee of the Education and Behavioral Sciences Section. Chicago, Il: Association of College and Research Libraries, American Library Association, 1996. 165p. ISSN 1060-5827. OCLC\#10713970. ISBN 0-8389-7862-2. OCLC\#36020928. $\$ 28.50$. 
The fourth edition lists and describes curriculum materials centers or collections at 278 institutions. Information is selfreported based on a questionnaire distributed during the summer of 1995. Entries give location, contact information, descriptive information, and comments. U.S. institutions are listed first, followed by Canadian, with both organized alphabetically by state or province. Includes institution index.

Drachler, Norman, comp. and ed. A Bibliography of Jewish Education in the United States. Detroit; Cincinnati: Wayne State University Press in association with American Jewish Archives, 1996. 727p. ISBN 0-8143-2353-7. OCLC\#19931129. \$29.95.

Covers all aspects of Jewish education in the U.S. from preschool through secondary education. Broadly organized into four parts: the schools, the profession, community and Jewish education, criteria and evaluation. Citation sources include educational and general periodicals, yeartooks, books, proceedings, bibliographies and encyclopedias. Intended for a diverse audience of lay leaders and educators, graduate and other students and scholars with an interest in Judaic studies and Jewish education. Includes about 600 doctoral dissertations and 400 master's theses.

Gale Encyclopedia of Psychology. Bernard Beins et al., eds. Detroit, Mich.: Gale, 1996. 435p. ISBN 0-77876-0372-4. OCLC\#35086060. \$99.00.

Describes key concepts in nearly 500 entries containing "see also" references and brief suggestions for further reading. Targets an audience of high school students, teachers, librarians, and social service professionals. Appendix of glossary, bibliography, and organizations. Indexes by subfield and by subject.

Glenn, Charles Leslie and Ester J. de Jong. Educating Immigrant Children: Schools and Language Minorities in Twelve Nations. New York: Garland Press, 1996. 741p. ISBN 08153-1469-8. OCLC\#34357831. \$75.00.

Compares school policies and practices for immigrant and language minority children within various $O E C D$ nations. The main focus is Belgium, the Netherlands, Germany, Denmark, Sweden, Switzerland, France, Spain, the United Kingdom, United States, Canada, and Australia. Chapters include indigenous language minority groups; immigrants and host societies; school programs for language minority children; and integrated education for language minority children. Provides a sixty-eight page bibliography of references.

The Government Financial Aid Book: The Insider's Guide to State \& Federal Government Grants and Loans. Researched and compiled by Student Financial Services. 2nd ed. Seattle, WA: Perpetual Press, 1996. 162p. ISBN 1-881199-31-2. OCLC\#34497531. \$9.95.
Provides prospective undergraduate and graduate students with information on obtaining govemment grants and federal student loans, filling out forms, and understanding financial aid criteria. Contains contacts for state aid programs, financial aid tips, and a section directed at high school students.

Gray, Maryann Jacobi et al. Immigration and Higher Education: Institutional Responses to Changing Demographics. Santa Monica: Rand, 1996. 117p. ISBN 0-8330-2381-0. OCLC\#34669223. \$15.00.

Reports on the effects of the continuing increase in immigration on higher education institutions based on a study of fourteen institutions in five regions of the country. Chapters cover immigrant access to higher education; academic support and retention; instruction for English as a second language; cocurricular programs. Bibliography included. One of three Rand reports on immigrants in the U.S. educational system: Newcomers in American Schools: Meeting the Educational Needs of Immigrant Youth (1993) and How Immigrants Fare in U.S. Education (1996).

Handbook of Educational Psychology. David C. Berliner, Robert C. Calfee, eds. New York: Macmillan Pub. USA, Simon \& Schuster Macmillan; London: Prentice Hall International, 1996. 1071p. ISBN 0-02-897089-6. OCLC\#33819564. $\$ 75.00$.

Focuses on the following areas viewed psychologically: leaming processes and leamer characteristics of students, the psychology of school subjects, teachers and their methods of instruction, and the social and institutional contexts of schooling. This technical volume, which emphasizes the American perspective, is geared toward practicing researchers, university teachers, and graduate students. It assumes prior knowledge in the fields of education, psychology, and educational psychology. Chapters generally have lengthy references.

Handbook of Gifted Education. Nicholas Colangelo, Gary A. Davis, eds. 2nd ed. Boston: Allyn and Bacon, 1997. 582p. ISBN 0-205-26085-3. OCLC\#34591000. \$57.60.

First published in 1991, this second edition expands the coverage of research and topics in the area of gifted education. Within six parts, fifty-six contributors in $\mathbf{4 4}$ chapters provide articles with bibliographical references: introduction; conceptions and identification; instructional models and practices; creativity, thinking skills, and eminence; psychological and counselling services; and special topics. Included among the coverage for special topics are articles pertaining to high IQ children; gifted performance in young children; gifted adolescents; gifted minority children; and international perspectives. Name and subject index. 
Handbook of Research for Educational Communications and Technology. David H. Jonassen, ed. New York: Macmillan Library Reference USA, 1996. 1267 p. ISBN 0-02-8646630. OCLC\#34658862. \$85.00.

Chapters are organized by major topics, which include foundations for research; hard technologies: media-related; soft technologies: instructional and informational design; instructional strategies; issues of organization and change; and research methodologies. Seventy-nine scholars have contributed to this work. Lengthy references follow each chapter.

\section{Handbook of the Undergraduate Curriculum: A Comprehensive} Guide to Purposes, Structures, Practices, and Change. Jerry G. Gaff, James L. Ratcliff, and associates. San Francisco, : Jossey-Bass, 1997. 747p. ISBN 0-7879-0289-6. OCLC\#34590929. \$55.00.

Provides an overview of the debates and reforms on undergraduate curriculum. Includes all aspects of the curriculum: purposes, origins, practices, trends, outcomes, obstacles and prospects. Describes different philosophies, frameworks, program designs, instructional strategies, and assessment methods being used with curriculum. Thirty-four chapters organized into six sections: historical, philosophical, and social perspectives; central aims of undergraduate education; academic disciplines and specialized leaming; directions for reform across the disciplines; administration and assessment of the curriculum; and changing the curriculum. Name and subject indexes.

International Handbook of Educational Leadership and Administration. Kenneth Leithwood et al., eds. Dordrecht: Boston: Kluwer Academic, 1996. 2 v. ISBN 0-79-23330-9. OCLC\#34409398. \$395.00.

Thirty-one chapters divided into five sections for a resource for practitioners or researchers. The first section provides an analysis of the context for educational leadership and administration across the intemational arena. Section two focuses on development of educational leaders and leadership. Section three covers cognitive perspectives on educational leadership and administration. Section four focuses on conceptions of educational leadership which have emerged overthe past several decades, primarily within North America, Europe, and Australia. Finally, section five contains seven chapters that review critical work on educational administration theory, research and practice. Chapter references, subject and name indexes.

The Internet for Teachers and School Library Media Specialists: Today's Applications, Tomorrow's Prospects. Edward J. Valauskas, Monica Ertel, eds. New York: Neal-Schuman Publishers, 1996. 231p. ISBN 1-55570-239-2. OCLC\# 34410364. \$24.99.
Essays, stories, and reports written by teachers, media specialists, and school administrators are grouped into four main parts. Part I is concerned with developing visions and creating infrastructures, Part II focuses on building models, Part III discusses integrating the Internet with the curriculum, and Part IV discusses both the technical and educational aspects of Web publishing in schools. A postscript deals with future educational applications. Appendixes include a bibliography, Internet site addresses, and an index.

Lippman, Laura et al. Urban Schools: The Challenge of Location and Poverty. Washington, DC: National Center for Education Statistics, U.S. Dept. of Educational Research and Improvement: For Sale by the U.S. G.P.O., Supt. of Docs., 1996. 1 v. (various pagings). ISBN 0-16-048669-6. OCLC\#35393727. \$14.00.

Describes public school students and their environments, and their educational and economic outcomes in the late 1980s to 1990. Using data from several national surveys, compares urban students and schools with their suburban and rural counterparts on a broad range of indicators, including student population and background characteristics, after school activities, school experiences, and student outcomes. A specific focus is how poverty relates to the characteristics of the students and schools studied. Executive summary, figures, charts and tables, data sources and definitions, and bibliography.

McCarthy, Jane. The Directory of Innovations in Elementary Schools. Larchmont, NY: Eye on Education, 1997. 321p. ISBN 1-883001-31-5. OCLC\#35212784. \$39.95.

Descriptions of innovative elementary schools nationwide intended to provide teachers, administrators, and others with a vision of possibilities. Three broad categories address building for change, structures that facilitate change, and teaching and learning for the 21 st century. Selected references and appendixes; index by state, directory of programs, and index of terms.

National Board for Professional Teaching Standards (U.S.). Middle Childhood/Generalist Standards for National Board Certification. Detroit, Mich. (300 River P1., Suite 3600, Detroit 48207): The Board, 1996. 49p. OCLC\#34990428. \$10.00.

Requirements for certification are organized into eleven standards. The report presents a summary of each standard, and an explanation of what teachers need to know, value and do if they are to satisfy the standard at a high level. Includes a list of standards committee members.

Philosophy of Education: An Encyclopedia. J. J. Chambliss, ed. New York: Garland Pub., 1996. 720p. ISBN 0-81-531177X. OCLC\#34590994. \$95.00. 
A reference work addressed to general readers, university students, and scholars. Contains 228 signed articles written by 184 authors. Covers philosophical points of view that have had the greatest influence on educational thinking, from ancient Greece to the present. Each article has a bibliography and a list of "see also" references. Name and subject indexes.

Ramsey, Robert D. The Principal's Book of Lists. Englewood Cliffs, N.J.: Prentice Hall, 1996. 402p. ISBN 0-13-4477499. OCLC\#34990196. \$31.45.

This practical guide for school administration presents a collection of school-tested models and suggestions on a wide range of topics, such as personnel, discipline, student services, athletics, curriculum review and development, staff development, crisis management, legal issues, and parent communication. Meant as a working tool, it contains a contents "List of Lists."

Renyi, Judith. Teachers Take Charge of Their Learning: Transforming Professional Development for Student Success. Washington, D.C.: The National Foundation for the Improvement of Education, 1996. 97p. OCLC\#35703795. $\$ 20.00$

The report presents the conditions and policies needed to incorporate teachers' leaming into their daily work in schools. Identifies incentives, processes, policies, and structures that support teachers' own learning.

Schwebel, Andrew et al. The Student Teacher's Handbook. 3rd ed. Nahway, N.J.: L. Erlbaum Associates, 1996. 267p. ISBN 0-8058-2130-9. OCLC\#344545539. \$24.95.

This practical guide covers the period of student-teaching assignments and the early teaching years. Among the topics covered are classroom management and discipline, cooperative learning, legal issues, special-needs students, multicultural education, and collaboration with school personnel and with parents. Each chapterhighlights major topics and critical issues. Bibliography of references.

Trends in the Well-Being of America's Children and Youth. U.S. Department of Health and Human Services, Office of the Assistant Secretary for Planning and Evaluation. Washington, DC: The Office, 1996. 342p. OCLC\#34838099 and \#35297136. \$12.00.

First annual report from U.S. Department of Health and Human Services, it presents the most recent national trends in five areas of the lives of children and youth: population, family and neighborhood; economic security; health conditions and health care; socialdevelopment, behavioral health, and teen fertility; and education and achievement. Report has two sections: section one is a quick-reference guide describing national trends for seventyfour indicators based on data collected by the Federal govemment; section two offers a narrative treatment of a particular topic such as the socio-demographic characteristics of children, youth and their families. References and detailed historical tables.

Tuma, John and Shelley K. Bums. Trends in Participation in Secondary Vocational Education: 1982-1992. Washington, D.C.: U.S. Dept. of Educational Research and Improvement, 1996. 61 p. OCLC\#3497809. \$4.50.

With additional data from 1990 National Assessment of Educational Progress High School Transcript Study and National Education Longitudinal Study of 1988 , analysis of vocational course-taking among public high school graduates was updated to encompass trends through 1992. Also expanded to include additional demographic characteristics such as disability status, parents' education, and limited-English proficiency status.

Vocational Education: Draft Standards for National Board Certification. Washington, D.C.: National Board of Professional Teaching Standards, 1996. 70p. OCLC\#35817851.

Requirements recommended by the Vocational Education Standards Committee for National Board Certification are organized into twelve summary standard statements. The twelve standards have been organized around student leaming. They are divided into three categories: creating a productive leaming environment; advanced student learning; professional development and outreach. Provides a summary of the standard and an explanation of what teachers need to know, value and do in order to satisfy the standard at a high level. Gives case histories from classrooms. Includes feedback form.

Wyman, Andrea. Rural Women Teachers in the United States: A Sourcebook. Lanham, MD: Scarecrow Press, 1996. 202p. ISBN 0-8108-3156-2. OCLC\#34321265. \$35.00.

Covers rural women who taught from the Colonial American period to the late 1930s and early 1940s. Six chapters include letters, diaries, and joumals; Amish women teachers, rural women teachers in fiction, and resources. Author and subject indexes.

Gladys I. Dratch is Collection Development Librarian and Deborah S. Garson is Head of Reference Services at Monroe C. Gutman Library, Harvard University, Graduate School of Education. 